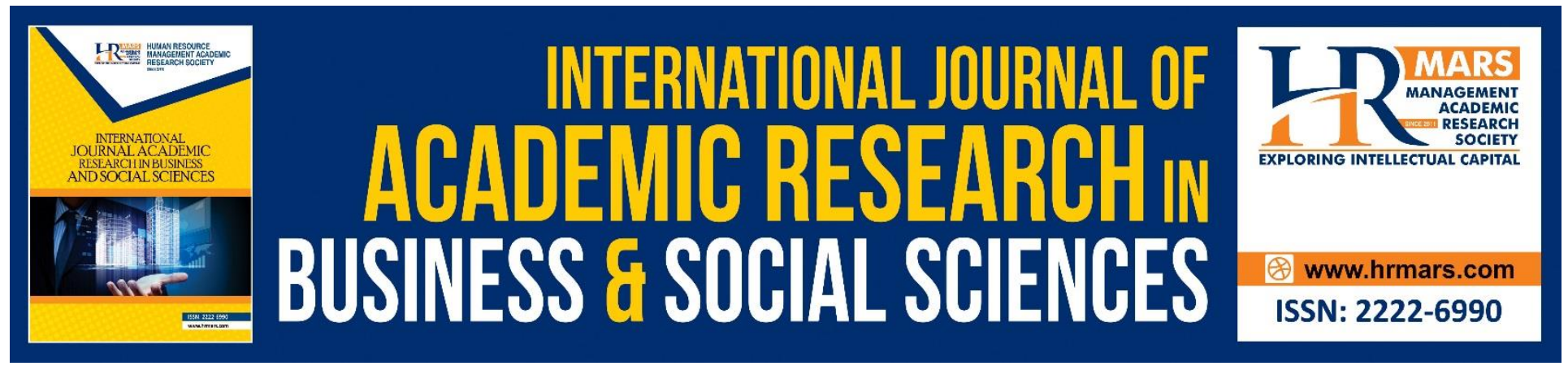

\title{
Personal, Financial and Job-Related Factors Affecting Malaysian Employees' Presenteeism in The Service Sector
}

\author{
Husniyah Abd. Rahim, Mohamad Fazli Sabri, Fatin Farwizah Mat Rahim, \\ Mohd. Amim Othman \& Amirah Shazana Magli
}

To Link this Article: http://dx.doi.org/10.6007/IJARBSS/v10-i16/8310

DOI:10.6007/IJARBSS/v10-i16/8310

Received: 12 September 2020, Revised: 17 October 2020, Accepted: 12 November 2020

Published Online: 30 November 2020

In-Text Citation: (Rahim et al., 2020)

To Cite this Article: Rahim, H. A., Sabri, M. F., Rahim, F. F. M., Othman, M. A., \& Magli, A. S. (2020). Personal, Financial and Job-Related Factors Affecting Malaysian Employees' Presenteeism in The Service Sector. International Journal of Academic Research in Business and Social Sciences, 10(16), 250-277.

\section{Copyright: (c) 2020 The Author(s)}

Published by Human Resource Management Academic Research Society (www.hrmars.com)

This article is published under the Creative Commons Attribution (CC BY 4.0) license. Anyone may reproduce, distribute, translate and create derivative works of this article (for both commercial and non-commercial purposes), subject to full attribution to the original publication and authors. The full terms of this license may be seen

at: http://creativecommons.org/licences/by/4.0/legalcode

Special Issue: Youth and Community Wellbeing: Issues, Challenges and Opportunities for Empowerment V2, 2020, Pg. 250 - 277

Full Terms \& Conditions of access and use can be found at http://hrmars.com/index.php/pages/detail/publication-ethics 


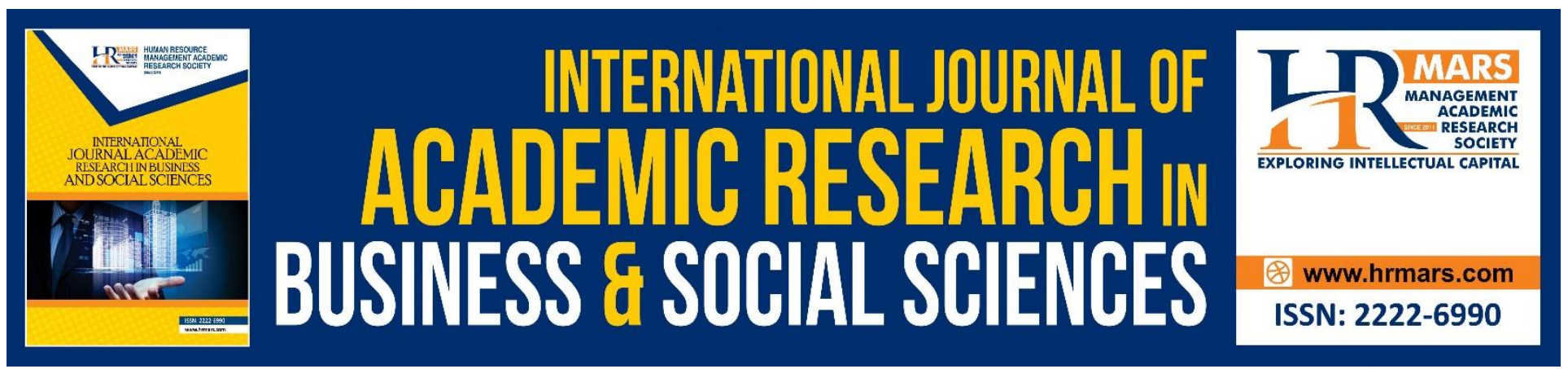

\title{
Personal, Financial and Job-Related Factors Affecting Malaysian Employees' Presenteeism in The Service Sector
}

\author{
${ }^{2}$ Husniyah Abd. Rahim, 1,2Mohamad Fazli Sabri, ${ }^{2}$ Fatin Farwizah Mat \\ Rahim, ${ }^{2}$ Mohd. Amim Othman \& ${ }^{2}$ Amirah Shazana Magli \\ ${ }^{1}$ Institute for Social Science Studies, Putra Infoport, Universiti Putra Malaysia, 43400 UPM Serdang, \\ Selangor, Malaysia, ${ }^{2}$ Department of Resource Management \& Consumer Studies, Faculty of Human \\ Ecology, Universiti Putra Malaysia, 43400 UPM Serdang, Selangor, Malaysia. \\ Email: fazli@upm.edu.my
}

\begin{abstract}
In paving success of an organization, job productivity among service sector employees is crucial. High management cost may be incurred by organizations in the long run when ignoring the factors contributing to a better job productivity. The job productivity concept is represented by absenteeism and presenteeism however the focus of this study is on presenteeism which is a state of behaviour where employees are present for work regardless of their current state of physical or psychological health. Personal, financial and job-related factors are determined their potential contributions for presenteeism among Malaysian employees in the civil service sector. Concentrating on service sector due to its main contribution on Malaysia gross domestic product (GDP), a cross-sectional survey and multi-stage random sampling was conducted resulting in 470 sets of data being analysed. The outcome of the study revealed factors such as locus control, materialism, work-life balance, financial stress and health as the factors that significantly affecting presenteeism of the service sector employees. The results will enable employers to develop appropriate intervention programs in enhancing the quality of personal, financial and job-related factors of the employees. Better services are expected to be offered by civil service agencies to the public as the outcomes are beneficial for both parties that are the customers and employees. Efficient time use by various parties would be the consequences of this action thus enabling the growth in economy.
\end{abstract}

Keywords: Financial Stress, Locus Control, Materialism, Presenteeism, Work-Life Balance.

\section{Introduction}

In paving the success of an organization, job productivity among service sector employees is crucial. Malaysia as a developing country is advancing towards a higher economy growth to achieve highincome status by 2020. Improvement in productivity is critical to sustain the positive trajectory in 
achieving its 2020 vision to become an advanced economy and inclusive nation (Malaysian Productivity Corporation, 2018). In the $11^{\text {th }}$ Malaysian Plan implementation, renewed efforts with visible outcomes to increase productivity have been the focus at all levels. Malaysia in its drive to boost productivity has increased its investment in capital in the previous two years in 2016 and 2017 in preparing itself for the Fourth Industrial Revolution, the Industry 4.0. In 2017, growth in labour productivity is registered in all the main economic sectors as compared to 2016 . The services sector registered a high productivity growth of 5.0 per cent which surpassed the $11^{\text {th }}$ Malaysian Plan target of 4.1 per cent growth and also has the largest contribution to total GDP at 54.5 per cent. This target is outlined in the Malaysia Productivity Blueprint introduced in May 2017 as a strategy to realize the aspiration of increased productivity.

High management cost organizations need to bear with may be incurred in the long run by ignoring the factors that contribute to a better job performance. Due to this, achieving high productivity and realizing results have been the most important objectives among the management levels. The overall productivity can be improved by increasing the efficiency of the inputs to increase outputs. Steering on improving the labour efficiency, the management levels should be able to identify factors which can help in improving the employees' productivity as a whole. Effects of employees' skills, physical and psychological health, payments and incentives on their job productivity were revealed in previous studies (Ali et al., 2017; Gosselin et al., 2013; Marzec, 2013; Muzamil \& Khurshid, 2014; Oloke et al., 2017; Berko et al., 2014). Improved understanding of chronic illness and presenteeism could enhance prediction of productivity loss and estimation of recoverable via health management strategies.

Malaysia has a target on improving the service sector by focusing on the productivity of employees in which acts as a catalyst for the greater income equity at all levels. The productivity level of the employees is expected to reach RM92,300 in 2020 as compared to RM81,039 in 2017 (Malaysian Productivity Corporation, 2018). Furthermore, the Public Complaints Bureau has a target to reduce complaint on public service sector. The move towards achieving a high-income nation in 2020 will be able to reduce the development gap with other newly industrialised economies such as South Korea (Economic Review, 2010). Due to the permanent status of employment among majority of the public service sector employees and retrenchment is not a way out for the low performance employees, it is important for government agencies to ensure those permanent workers display high performance for the sake of the nation.

Job productivity nevertheless is important as it includes the intangible values of the organization such as reputation that might lead towards achieving a high-income nation in 2020. Low job productivity however is a cost to an organization which may be due to various factors including personal factors. The causes for the productivity lose and indirect costs for organizations can be absenteeism and presenteeism. Absenteeism can be easily measured as the employee is obviously absent from work. But presenteeism is difficult to determine (Schultz et al., 2009) and loss of productivity is greater with presenteeism than absenteeism (Baker et al., 2010). Employees who are present at work with low efficiency while receiving a full salary might reduce the productivity of enterprises or organizations (Pit \& Hansen, 2016). 
The Household Income and Basic Amenities Survey in 2019 reported an average monthly income of Malaysian households of RM7,901 in 2019 with a growth rate of 4.2 per cent annually (Department of Statistics Malaysia, 2020). In spite of this, households are reflected to experience low financial well-being and are in high debt. The mean monthly household consumption expenditure for Malaysia from the Household Expenditure Survey Report 2019 showed an increase from RM4,033 in 2016 to RM4,534 in 2019 at a growth rate of 3.9 per cent per annum and this rate is almost parallel with the rate of income (Department of Statistics Malaysia, 2020). In terms of debt, the amount of debt causes from car loans alone accounted for 21.53 per cent from the total bankruptcy cases from the year 2015 to 2019 (Malaysian Department of Insolvency, 2020). While a total of 5.97 per cent bankrupts were among public sector workers as compared to the total bankruptcy for the same period. For the number of bankrupts, a total of 8,481 consumers were declared bankrupt due to credit card debt which was 10.00 per cent from the total bankrupt. The constraint consumption and high level of indebtness among employees may develop financial stress.

These statistics were supported by past studies revealing the positive relationships between personal and household debt with financial stress (Abdullah et al., 2019; French \& McKillop, 2017; Sweet et al., 2013; Worthington, 2006). Employees facing financial stress may be experiencing a low motivation in their work and will divert their attention from work. The effect on employee productivity due to personal financial wellness was revealed through a seminal study in an earlier study (Joo, 1998). Employee productivity measured by absenteeism and work time use was found to be significantly influenced by financial wellness in the study. Financially unwell employees would more likely be using up work time to settle personal financial matters (Delafrooz et al., 2010). Employers will be losing job productivity and this is a cost for employers especially for public services as salary is not a function of productivity.

High spending behaviour individuals tend to purchase more than necessary as they can be a materialistic person who purchased to reflect certain value and involved in high consumption. Employees displaying highly materialistic values are associated with a lower quality of work life, having shown negative organizational citizenship behaviour and intensified work-family conflict (Deckop et al., 2015; Promislo et al., 2010). These reflected the unbalanced work-life scenario among the employees.

The job productivity in this study will be determined by presenteeism which is defined as the condition in which employees are present at work but are not at peak performance due to illness or other health-related problems (Yu et al., 2015). Presenteeism has been shown to be the cause for over $60 \%$ of the economic losses due to poor employee health; with the remainder due to medical costs, pharmacy, absenteeism and disability (Edington \& Burton, 2003). While Chinese researchers reported that productivity loss caused by presenteeism is nearly $50 \%$ greater than the productivity loss due to absenteeism (Xiaoqian \& Jianshi, 2010). This justified the focus on presenteeism to reflect job productivity in this study. 
Hence, this study aims to identify the extent of influences from personal, financial and job-related factors such as locus of control, materialism, work-life balance, financial stress and health on job productivity specifically presenteeism among employees in the service sector. The focus on the service sector is due to its main contribution to Malaysia gross domestic product (GDP) as compared to other sectors. Services dominated the diversified economy of Malaysia with 55 per cent contribution on the GDP while manufacturing sector contributed a quarter part of the economy followed by other sectors such as mining (8\%) and agriculture (7\%) (IMF, 2015).

\section{Literature Review}

Job Demands-Resources Model

The Job Demands-Resources Model (JD-R) was earlier published by Demerouti et al. (2001) in understanding the antecedents of burnout and only considered characteristics of the work environment (Yang et al., 2016). It represents a way of thinking how job characteristics could influence employee health, well-being and motivation. Recently personal factors are included in the scope of the JD-R, hence includes all job demands and job resources. The integration of personal resources in the model arise from human behavior are involved in the interaction between personal and environmental factors. Personal resources are defined as the psychological characteristics that are generally associated with resiliency which refer to the ability to control and impact one's environment successfully. In this study, this was represented by locus of control, materialism and health.

The model is able to interpret the relationships among job stressors, health, individual factors and presenteeism (Yang et al., 2016). Whenever job demands are high with few job resources, job demands may turn into high-level of job stressors, leading to health problems and other consequences. As job demands need to be satisfied in order to perform well, employees with specific personality traits will pretend to work hard in the workplace without any absence, though they are sick or not working at full productivity (Hobfoll, 2001). Additionally, personality traits were found to be significantly associated with increased expression of pro-inflammatory genes (Vedhara et al., 2015) and thus affecting the health and productivity of employees.

Yang et al. (2016) applied the JD-R Model in the expectation that the model can be an explanatory model for a negative relationship between stress-related factors at work and presenteeism and between individual factors and health. Furthermore, they investigated the mediated effects of health on the relationship between stress-related factors at work and presenteeism, taking into account individual factors. They investigate the concerns of employers about the productivity of their organizations because the physical and cognitive capabilities of the aging workforce might decrease with age.

\section{Socio-economic characteristics}

Past results indicated that there were significantly higher prevalences of presenteeism in employees with a number of demographic, health and psychosocial characteristics (Aronsson et al., 2000; Cancelliere et al., 2011; DiBonaventura et al., 2011; Schultz \& Edington, 2007; Steultjens et al., 2012; Terry \& Xi, 2010). 
Empirical studies on gender differences in sickness presenteeism show conflicting results; some find higher presenteeism among women than men (Bockerman \& Laukkanen, 2010; Leineweber et al., 2011) while others find no gender differences (Rosvold \& Bjertness, 2002). Due to the different family burden and its effect, it has also been suggested that the family situation influences women's health more than men's health (Patton \& Johns, 2007). Marital status has been related with health problems in women, but to fewer health problems in men (Emslie et al., 1999). Sick leave among women has been related with women's greater family responsibilities and research from Sweden shows that illness among women increases after the second child is born (Angelov et al., 2013). Sweden is considered as one of the most gender equal countries in the world (Greig et al., 2006) however gender equality is in the work place, but not in the family explains the deteriorating health among Swedish women.

Gender was found to have an effect on presenteeism where female physicians reported sickness presenteeism more often than male physicians. It was also revealed the function of work-family conflict in mediating the association between gender and sickness presenteeism (Gustafsson et al., 2016). Reasons reported among women related with "concern for others" and "workload" was more strongly than men. Whilst reasons reported among men related with "capacity" and "money" was more strongly than women. These differences are likely due to gender stereotyping and different family-responsibilities.

Past study on workers in a Chinese enterprise revealed no significant difference in presenteeism between workers based on household income or education level (Yu et al., 2015). However, presenteeism was more common in males, employees aged between 20 to 35 years old, either single/divorced/widowed employees apart from factors such as life dissatisfaction, job dissatisfaction, overweight/obese employees, current cigarette smokers and current alcohol drinkers. They found that younger workers had a higher prevalence of presenteeism than older workers. Older workers may have more experience and operation skills as compared with younger workers. In addition, males had a higher prevalence of presenteeism than females. This finding supports the results of a similar study by Barclay (2013). This can be justified that males in maledominated workplaces appeared to engage more in risky health behaviours, such as unhealthy dietary patterns, and are also less likely to take time off work when they are sick. Married employees with greater economic, health and psychological support at home were found to have a lower prevalence of presenteeism.

\section{Presenteeism}

Productivity can be used to measure individuals and organization performance (Noe et al., 2016) and job productivity of employees is a combination of both absenteeism and presenteeism. Schultz et al. (2009) stated that presenteeism is often measured as the costs associated with reduced work output, errors on the job and failure to meet company production standards. While Baker et al. (2010) mentioned that the impact of presenteeism is hard to measure. Gosselin et al. (2013) contended that presenteeism is a state of behaviour in which employees come to work despite of their current state of physical or psychological health. Absenteeism is referred as employees taking time off work either 
due to an illness or not (Beaton et al., 2009). Previous studies have determined factors affecting absenteeism and presenteeism among employee such as stress (Marzec, 2013), health (Gosselin et al., 2013), working hours (Yildiz et al., 2015), emotional dissonance and quality of work-life balance (Celik \& Oz, 2011), work environment and individual motivation (Collins \& Cartwright, 2012).

Presenteeism is considered as a key indicator for assessing recessive productivity loss, where it is the act of attending work while unable to perform effectively because of health problems (Aronsson et al., 2000; Dewa et al., 2004). The costs of presenteeism in the enterprises in the United States, have accounted for 62 per cent of total expenditures of employees' salaries since 2000, while those of medical treatment and absenteeism have accounted for 24 and 6 per cent, respectively (Hemp, 2004). Meanwhile, perceived work ability has been ascertained as a robust indicator of presenteeism due to its ability to indicate potential productivity loss by measuring the extent to which participants feel that they cannot fulfil demands while they are still working (Vänni et al., 2012). Yang et al. (2016) defined presenteeism as reduced productivity at work due to health problems or other events that distract one from full productivity and it is often related to health outcomes for employees and stressrelated factors at work (Van den Heuvel et al., 2010).

The prevalence of presenteeism was 15 per cent (Yu et al., 2015) among petrochemical workers in a Chinese enterprise. Among the main determinants of presenteeism investigated in previous studies were stress-related factors at work, health, and individual factors. Stress-related factors at work are the unavoidable work content and work context due to the demands of the contemporary work environment, such as high work demands and work control and poor social climate which make great contributions to presenteeism (Johns, 2010; Karlsson et al., 2010). Previous studies also have discovered the underlying factors which can affect job productivity such as work-life balance, leadership skills of higher personnel, payments, security of job, transparency and accountability of management, policies and job specification (Ailabouni et al., 2010; Muzamil \& Khurshid, 2014), employee skills (Ali et al., 2017) and incentives (Oloke et al., 2017).

\section{Locus of Control}

Locus of control is the degree to which individuals believe that their actions influence what happens to them (Williams, 2007). It is a personality trait indicating the extent to which individuals believe that they have control over what happens to them in life. It also represents a belief in oneself relative to one's environment (Dormann et al., 2006). Individuals with high internal locus of control have a strong desire of control, and this motivation represents the positive valence to the goal of feeling (Krishnan et al., 2003). High internal locus of control individuals believe that whatever happens to them is largely a result of their choices and actions. These will have great effect on their outcomes and hence will put more efforts in their job (Leone \& Burns, 2000). High external locus of control individuals on the other hand, believe that external forces outside of their control caused what happens to them. The concept of self-efficacy emphasised more on confidence with respect to actions or behaviours is different as compared to locus of control which focuses more on confidence in being able to control outcomes. 
Lim and Teo (1998) found that internal locus of control individuals tends to have higher level of organizational commitment than externals. Generally, internals are more likely to adopt proactive, problem-solving means in their effort to change the environment, and are more likely to engage in goal-directed activities (Hoffman et al., 2003). Thus, it would be expected that internals would have higher goal commitment. Internality is associated with being more involved in work, reduced absenteeism and exerting more control in many aspects of a job (Carrim et al., 2006). Previous studies also showed that locus of control strongly related to job satisfaction (Leone \& Burns, 2000, Lim \& Teo, 1998). The main reason why internals are more satisfied with their jobs is their ability to control situations. Chen and Silverthorne (2008) reported that workers with internal locus of control could easily cope with job stress. The findings indicated that one aspect of personality, as measured by locus of control, played an important role in predicting job performance in Taiwan. Individuals with a higher internal locus of control were more likely to have higher levels of job performance as they perceived lower levels of job stress arising from the job.

\section{Materialism}

Materialism is proposed as the extent in which individuals engage in the development and maintenance of self through the acquisition of products, services and experiences (Shrum et al., 2013). It encouraged people to work more leading to generating higher incomes to finance a greater consumption and higher living standards (Kasser et al., 2007). Materialism can be a motivation for individuals, however there are growing concerns among researchers that materialism can give more negative consequences to individuals such as growing amount of debt, depression and greed (Tsang et al., 2014).

Possessions and acquisitions are put forth by materialists and considered as the priority in their life and perceiving materialism as a source of success and happiness (Richins \& Dawson, 1992). Previous studies revealed that materialists are willing to take on greater levels of debt (Ponchio \& Aranha, 2008) and displaying more positive attitudes toward debt (Pirog \& Roberts, 2007). Thus they have high potential to involve in compulsive purchases (Dittmar, 2005) than non-materialists. In conjunction to that, individuals using fewer money management strategies are typically more materialistic (Garoarsdottir \& Dittmar, 2012). High materialism was found to be negatively associated with financial satisfaction (Tang et al., 2011). Recent research suggests that the negative association between materialism and well-being spills over to workplace. This is because those displaying highly materialistic values are associated with a lower quality of work life (Deckop et al., 2010), showing negative organizational citizenship behaviour (Deckop et al., 2015). They also experienced increased work-family conflict (Promislo et al., 2010).

Work-life balance

Work-life balance is the balanced combination between different aspects of life with the concept of both the work life and the personal life compliments each other (Abendroth \& Dulk, 2011). In a similar manner, Daipura and Kakar (2013) defined work-life balance as the state of achieving a balance between work and life requiring pleasant feelings with both commitments. Nevertheless, majority of work-life studies have defined work-life balance in terms of the level of work-life conflict (Carlson et al., 2009). A cross-sectional survey of 980 working Australians measured the relationships between 
job demands such as work-family conflict apart from resources (leadership and social support), burnout, work engagement and presenteeism (McGregor et al., 2016). Higher job demands (workfamily conflict) and lower job resources (leadership only) were found to be indirectly related to presenteeism via increased burnout. Competitiveness and globalisation have made work life balance being considered by organizations (Ghalawat \& Sukhija, 2012) while McShane and Glinov (2010) has found that work life balance can affect the conflicts between workplace and non-work activities of employees. In reducing the negative effects of work life imbalances, personal leaves and child care support have gained importance (McShane \& Glinov, 2010).

A significant number of empirical studies have showed that work-life balance is positively related to employees' performance and organizational performance (Harrington \& Ladge, 2009; Mendis \& Weerakkody, 2014; Rego \& Pina e Cunha, 2009). Employees who successfully fulfill the role and commitment of families will demonstrate more excellent job performance. Specifically, work-life balance has been shown to have positive outcomes, such as increase in job satisfaction, commitment and productivity (Mukururi \& Ngari, 2014), and increasing employees' job satisfaction as a whole (Kamran et al., 2014; Mas-Machuca et al., 2016). However, it was also revealed that poor work-life balance among the employees will negatively affect their perceived job stress, hence reducing the productivity of the employees (Bell et al., 2012). In a local study among university staffs in northern Malaysia, work-life balance, job satisfaction and organizational commitment are found to be positively correlated with the dependent variable which is employee performance (Hussein et al., 2018). Johari et al. (2018) in their study among teachers in public school in Northern region of Peninsular Malaysia reported that autonomy and work-life balance had a significant impact on respondents' job performance.

\section{Financial Stress}

Financial stress is perceived to be one of the most important sources of psycho-social stress because so many of the basic activities of daily life are associated with personal financial resources and their management (Peirce et al., 1996). Past studies have confirmed financial stress as among the determinants for individual financial well-being (Delafrooz \& Paim, 2011; Mokhtar \& Husniyah, 2017; Sabri et al., 2020). Most studies focus on the effect of stress on presenteeism. One such study among Malaysian urban employees from 47 private companies revealed factors that predict both absenteeism and presenteeism which were income, general physical health, sleep length and being unwell due to stress (Wee et al., 2019). For a study on mental health, higher rates of absenteeism and presenteeism were found to be associated with stress (Brborovic et al., 2016; Bubonya et al., 2017; Marzec et al., 2015). Earlier, Halkos and Bousinakis (2010) found that increased stress leads to reduced productivity and increased satisfaction of employees leads to their increased productivity. Where workers' personal life starts to interfere with work, this implies a negative effect on productivity. The results of a regression analysis indicated that almost 50 per cent of the total stress score was predicted by the financial stress scores (Bailey et al., 1998). Similarly, it is expected that increased financial stress will lead to reduced productivity.

Few studies assessed the extent of workers financial concerns interfering with their work life. While no empirical study had done specifically on the influence of financial stress on presenteeism. 
However, there were studies using absenteeism instead of presenteeism. Nevertheless, the result from the studies (Kim \& Garman, 2003; Kim et al., 2006) found a negative association between employees' financial stress with absenteeism that can be used to relate to presenteeism as absenteeism is another measure of job productivity. Clients with high levels of financial stress are more likely to experience higher levels of absenteeism; thus spending work hours handling personal finances, which decreases the time they are at work. Hence, the same influence is expected from financial stress on presenteeism of employees. Earlier, Williams et al. (1996) contended that there was a negative and direct relationship between financial problems and productivity. Facing more financial problems would result in low job productivity. Employees were experiencing financial stress that gave an impact on their productivity. Later Joo (1998) found that a higher level of financial wellbeing was related with better job performance.

\section{Health}

Health is related to job productivity in such a way that unhealthy employees would result in lowered job productivity. As presenteeism is a condition whereby an unhealthy employees are still present at work, however with a deteriorating health condition leading to less productive performance. Health not only leads to presenteeism but is also considered as a mediator between stress-related factors at work and presenteeism (Gosselin et al., 2013; Karlsson et al., 2010; Vahtera et al., 2000; Yang et al., 2016; Yu et al., 2015). In line with this, both individual factors, such as personality traits, and health have been found to lead to presenteeism (Aronsson \& Gustafsson, 2005). Higher prevalence of presenteeism in employees with health apart from psychosocial characteristics was also indicated in other past studies (Cancelliere et al., 2011; DiBonaventura et al., 2011; Schultz \& Edington, 2007; Steultjens et al., 2012). Employees in a Chinese enterprise with high blood pressure, hypertriglyceridemia, hypercholesterolemia, insufficient physical activity, insufficient cereal intake and high health risk grade showed that the prevalence of presenteeism was significant (Yu et al., 2015). Presenteeism increased with increasing health risk grade among these employees. Participants in the high health risk grade reported the highest prevalence of presenteeism.

\section{Methodology}

Information regarding personal factors and job-related factors apart from socioeconomic characteristics are obtained from a cross-sectional design using survey method. The study was focused on civil service sector employees working in Malaysia to reveal the presenteeism among service sector employees. The population of the civil service is 1.4 million employed in 28 schemes of Malaysian service under the Public Services Department that include the federal public service, state public services, joint public services, education service, judiciary, legal service, police and armed forces. As suggested by Fox et al. (2007), a sample of 384 is adequate for this population however a higher number is decided that is $\mathbf{5 0 0}$ samples targeted after considering the differences between group analyses. Utilising a multi-stage random sampling, in the first stage, five states were randomly selected from five zones in Malaysia targeting a total of 100 respondents in each state. Based on a list of the departments from the government agency websites, service sector departments were selected at the second stage of random sampling. Assisted by a liaison officer from the selected department, respondents were chosen from a list of employee names and their consents were sought 
before the distribution of the questionnaires. After two to three weeks at the various departments, a total of $\mathbf{4 7 0}$ questionnaires were collected from the liaison officers.

Previously published researches were referred to in obtaining established measurements for the variables. Information on socioeconomic characteristics, personal factors (locus of control, materialism, health), financial factor (financial stress) and also job-related factors (work-life balance, presenteeism) were collected. A questionnaire was developed as the tool for the survey. Locus of control gave a high reliability value of 0.954 for its seven items in this study. To examine materialism as a facet of consumer behaviour, material values (MV) scale developed by Richins (2004) using 18 items with five responses from strongly disagree to strongly agree was used giving a reliability of 0.646 in this study. Adapting items from Patel et al. (2016) and Delafrooz and Laily (2013) for financial stress having six statements with five scales from never to most often resulted in a high reliability of 0.899. Health condition was measured with a single item which required a response on this question "In the last 4 weeks, to what extent does the daily activities (including work outside and inside the house) are interrupted due to body pain?" The scale by Netemeyer et al. (1996) was used for worklife balance having nine items with five scales from strongly disagree to strongly agree resulting in a high reliability of 0.829 for this adopted scale.

Presenteeism measurement of an employee was adapted from World Health Organization Health and Work Performance Questionnaire (Kessler et al., 2003). It has five scales ranging from least often to most often with reliability value of 0.875 for seven items. Loss of productivity in terms of presenteeism was identified based on the frequency of experiencing difficulties at work. It reflects the difficulties experienced on the job however with some difficulty or inefficiency. Through EDA, distributions of the data for the continuous variables were confirmed to be normal thus assumptions for multiple regressions were fulfilled by the data.

\section{Results and Discussion Profile of Respondents}

The profile of respondents is displayed in Table 1 which shows the background information of the employees in the public service sector in this study. More than half of the respondents $(60.2 \%)$ were female and about three quarter were Malay ethnicity (82.1\%) and single (71.3\%). In terms of the education level, there are about the same proportion of non-graduate and graduates among these employees. Slightly more than two-third of them (68.8\%) were young workers with half $(49.2 \%)$ of them had been working less than 10 years.

In terms of respondent's income, those earning less than RM3,000 a month was 65.0 per cent of the respondents while those earning more than $\mathrm{RM} 3,000$ a month were only one third of them (35.0\%). Respondents earning more than RM3,000 may include graduates who are half of the respondents and those with working tenure of more than 20 years $(20.5 \%)$. The median income in this study was in the range of between RM750 to less than RM3,000 monthly incomes. As for household income, an income of less than RM3,000 a month is considered as urban poor that consists of almost half (45.6\%) of the respondents. This may reflects the low financial situation among these employees and may contribute to financial stress. 
Only a total of 20.2 per cent (only one-fifth) of the respondents obtained at least RM6,000 a month and may be among those who are married (24.9\%), graduates $(49.8 \%)$ or those with longer work tenure (20.5\% working more than 20 years). The median household income laid in the range of RM3,000 to RM6,000 monthly. This is in accordance with the median monthly household income for Malaysian population which was RM5,873 for 2019 (Department of Statistic Malaysia, 2020). This reflects the sample representativeness of the population.

Table 1: Profile of respondents

\begin{tabular}{|c|c|}
\hline Background of respondent & $n(\%)(n=470)$ \\
\hline \multicolumn{2}{|l|}{ Gender } \\
\hline Male & $187(39.8)$ \\
\hline Female & $283(60.2)$ \\
\hline \multicolumn{2}{|l|}{ Race } \\
\hline Malay & $386(82.1)$ \\
\hline Chinese & $2(0.4)$ \\
\hline Indian & $3(0.6)$ \\
\hline Bumiputra Sabah/ Sarawak & $79(16.8)$ \\
\hline \multicolumn{2}{|l|}{ Marital Status } \\
\hline Single & 335 (71.3) \\
\hline Married & 117 (24.9) \\
\hline \multicolumn{2}{|l|}{ Education } \\
\hline Primary school & $8(1.7)$ \\
\hline$P M R / S R P / L C E$ & $24(2.4)$ \\
\hline SPM/MCE & $138(29.4)$ \\
\hline STPM/HSC/Certificate & $66(14.0)$ \\
\hline Diploma & $119(25.3)$ \\
\hline Bachelor & $95(20.2)$ \\
\hline Master & $20(4.3)$ \\
\hline \multicolumn{2}{|l|}{ Age (year) } \\
\hline $21-30$ & $128(27.6)$ \\
\hline $31-40$ & $191(41.2)$ \\
\hline $41-50$ & $92(19.8)$ \\
\hline $51-60$ & $53(11.4)$ \\
\hline \multicolumn{2}{|l|}{ Work Tenure (year) } \\
\hline$\leq 10$ & $216(49.2)$ \\
\hline $11-20$ & $133(30.3)$ \\
\hline $21-30$ & $64(14.6)$ \\
\hline $31-40$ & $26(5.9)$ \\
\hline \multicolumn{2}{|l|}{ Respondent's Income } \\
\hline$<$ RM750 & $33(7.2)$ \\
\hline RM750 - < RM3,000 & $246(57.8)$ \\
\hline RM3,000 - < RM6,000 & $147(32.2)$ \\
\hline RM6,000 - < RM9,000 & $22(4.8)$ \\
\hline
\end{tabular}




$\begin{array}{lc}\text { RM9,000 - < RM12,000 } & 9(2.0) \\ \text { Household Income } & \\ <\text { RM750 } & 37(8.4) \\ \text { RM750 - < RM3,000 } & 164(37.2) \\ \text { RM3,000 - < RM6,000 } & 151(34.2) \\ \text { RM6,000 - < RM9,000 } & 56(12.7) \\ \text { RM9,000 - < RM12,000 } & 21(4.8) \\ \text { RM } \geq 12,000 & 12(2.7)\end{array}$

\section{Inferential Analysis for Variables}

Correlation analyses results to determine the significance of independent variables with presenteeism are presented in Table 2. Work-life balance $(r=-0.475 ; p=0.000)$ was revealed as having the strongest correlation with presenteeism however having a moderate strength due to its coefficient value of more than 0.41 (Guilford, 1973). Financial stress $(r=0.356 ; p=0.000)$, materialism $(r=0.331 ; p=0.000)$, locus of control $(r=-0.325 ; p=0.000)$ and health $(r=0.303 ; p=0.000)$, all had weak correlations ( $r=0.21$ to 0.40 ) with presenteeism.

An employee having a higher work-life balance would more likely to display lower presenteeism during work as shown by the negative correlation between them. Having a more balanced time between work and their life would satisfy them more with their life and hence may be portrayed at work. As for financial stress and materialism, with the positive relationships, higher scores of these concepts are related to higher presenteeism. Thus, by being financially stressful and a materialistic individual, they would be displaying higher presenteeism. Experiencing stress regarding finances is due to ffinancial problems which often affect an individual's level of work productivity and personal relationships as contended by Williams et al. (1996). Materialistic individual as suggested through research extends to workplace outcomes. Those displaying highly materialistic values are found to be associated with a lower quality of work life (Deckop et al., 2010).

Table 2: Correlation analysis with presenteeism

\begin{tabular}{lcc}
\hline \multicolumn{1}{c}{ Variables } & \multicolumn{2}{c}{ Presenteeism } \\
& Pearson Correlation & Sig. (2-tailed) \\
\hline Work tenure & $-.099^{*}$ & .040 \\
Age & $-.103^{*}$ & .027 \\
Locus of control & $-.325^{* *}$ & .000 \\
Materialism & $.331^{* *}$ & .000 \\
Work-life Balance & $-.475^{* *}$ & .000 \\
Financial Stress & $.356^{* *}$ & .000 \\
Health (unhealthy) & $.303^{* *}$ & .000 \\
\hline
\end{tabular}

$* * p \leq 0.01 ; p \leq 0.05$

Locus of control which was in the same class of strength of relationship with financial stress and materialism, however exhibited a negative relationship with presenteeism. Internally locus of control 
employees would likely to be able to control themselves during work hence focusing more on the job task. This is because locus of control is the degree to which people believe that their actions influence what happens to them (Williams, 2007). Thus, they display less presenteeism situation while they are at work. Health condition of an employee does have a significant correlation with presenteeism which in this study, the concept measures the unhealthy condition of the employee. Unhealthy employees will more likely be displaying presenteeism, where they will come to work even when they are not fit for work. This may be a way to show a good record of attendance to avoid any negative consequences due to bad attendance record.

Work tenure $(r=-0.099 ; p=0.040)$ and age $(r=-0.103 ; p=0.027)$ of the employee were also found to be significantly related to presenteeism but had negligible relationships $(r<0.20)$. The negative relationships meant that the longer the employee is in service or the longer the employee lives, the lower the presenteeism of the employee. This may be due to their loyalty towards their organization hence they will put their effort to be more productive at work.

Table 3 displays the differences in presenteeism based on gender, education level, respondent's income and household income of the employees. Gender was not found to be able to differentiate employees in terms of presenteeism as found by Rosvold and Bjertness (2002). The most highly significant difference in presenteeism was for household income followed by the respondent's income and education. However, Yu et al. (2015) found no significant difference in presenteeism between workers in a Chinese enterprise by household income or education level. Those employees having household income of at least RM6,000, earning at least RM3,000 a month and were graduates showed lower presenteeism as compared to those earning household income of less than RM6,000, earning less than RM3,000 a month and non-graduates. The higher the potential cash-flow from their own income or family, they will be less worrying about finances and thus can concentrate more on their job leading to lower presenteeism. Education also was able to differentiate presenteeism among employees however at a lower confidence level of 95 per cent as compared to income which is at the 99 per cent confidence level.

Table 3: Differences in presenteeism based on back-ground

\begin{tabular}{lccccc}
\hline & Category & $\begin{array}{c}\text { Mean } \\
(7-35)\end{array}$ & $\begin{array}{c}\text { Std. } \\
\text { Dev. }\end{array}$ & $\mathrm{t}$ & Sig. \\
\hline Gender & Female & 17.1828 & 5.02307 & .614 & .539 \\
& Male & 16.8881 & 5.11729 & & \\
Education & Non-graduate & 17.5498 & 4.99181 & $2.309 *$ & .021 \\
& Graduate & 16.4655 & 5.11247 & & \\
Respondent's & $<$ RM3,000 & 17.7076 & 4.82720 & $2.879 * *$ & .004 \\
Income & $\geq$ RM3,000 & 16.2821 & 5.15038 & & \\
Household Income & $<$ RM6,000 & 17.5559 & 5.05150 & $4.343 * *$ & .000 \\
& $\geq$ RM6,000 & 14.9302 & 4.89607 & & \\
\hline
\end{tabular}

$* * p \leq 0.01 ; * \leq 0.05$ 
INTERNATIONAL JOURNAL OF ACADEMIC RESEARCH IN BUSINESS AND SOCIAL SCIENCES

Vol. 10, No. 16, Youth and Community Wellbeing: Issues, Challenges and Opportunities for Empowerment V2. 2020, E-ISSN: 2222-6990 @ 2020 HRMARS

\section{Factors Affecting Presenteeism of Employees}

The validity and fitness of the models were determined prior to explaining the results of multiple regression analyses for presenteeism model. Five models were regressed with presenteeism as the dependent variable. The input for the first model is the respondent's background which were significant in the correlation analyses to act as control variables. Though gender was not found to be significant in its correlation with presenteeism in this study, gender was included based on its significant relationship with presenteeism from past studies (Bockerman \& Laukkanen, 2010; Gustafsson et al., 2016; Leineweber et al., 2011). The following models were added with variables from the personal, financial and job factors that are locus of control, materialism, financial stress, work-life balance and health. These hierarchical regression models were found to be valid models justified by significant F-statistics with the final model for presenteeism having an $\mathrm{F}$ value of 20.903 (sig. $F=0.000$ ) based on the ANOVA tables output. There was no issue of multi-collinearity for the independent variables by referring to the tolerance and VIF values for the variables that is far from the border of more than 0.1 for tolerance and less than 10 for VIF.

The multiple regressions' result of the presenteeism models' fitness revealed the extent of presenteeism's variance explained by the independent variables of personal and job factors in the models. The final model as displayed in Table 4 was able to explain 39.2 per cent of the variation in presenteeism based on the coefficient analysis of determination ( $R$ square) which include personal and job factors controlling with back-ground variables. Locus of control and materialism which are personality variables contributed a total of 21.7 per cent of the explained variance which is half of the explained variance of the final model. The $\mathrm{R}$ square change for the inclusion of work-life balance in the model was 10.1 per cent, financial stress was 1.6 per cent and health was 1.7 per cent. This showed that locus of control, materialism and work-life balance were among those variables that contributed high in explaining the variance in presenteeism. Financial stress and health are found to be contributing less to presenteeism as compared to personality and job factors. The back-ground of the respondents comprising of gender, education, income of respondent and household income, work tenure and age contributed only a total of 4.2 per cent on the explained variance of presenteeism which also reflected a significant contribution from the respondent's back-ground variables.

Table 4: Fitness of the presenteeism model

\begin{tabular}{cccccc}
\hline Model & $\mathrm{R}$ & $\mathrm{R}$ & Adjusted R & \multicolumn{2}{c}{ Change Statistics } \\
& & Square & Square & R Square Change & Sig. F Change \\
\hline 1 & $.204^{\mathrm{a}}$ & .042 & .026 & .042 & .017 \\
2 & $.508^{\mathrm{b}}$ & .258 & .242 & .217 & .000 \\
3 & $.599^{\mathrm{c}}$ & .359 & .343 & .101 & .000 \\
4 & $.612^{\mathrm{d}}$ & .375 & .358 & .016 & .003 \\
5 & $.626^{\mathrm{e}}$ & .392 & .373 & .017 & .002 \\
\hline
\end{tabular}

a. Model 1: Male, graduate, respondent's \& household income, work tenure, age

b. Model 2: Male, graduate, respondent's \& household income, work tenure, age, locus of control, materialism 
c. Model 3: Male, graduate, respondent's \& household income, work tenure, age, locus of control, materialism, work-life balance

d. Model 4: Male, graduate, respondent's \& household income, work tenure, age, locus of control, materialism, work-life balance, financial stress

e. Model 4: Male, graduate, respondent's \& household income, work tenure, age, locus of control, materialism, work-life balance, financial stress, health

The regression results for Model 1 in Table 5 displayed positive and significant result towards presenteeism only for household income $\left(b=-1.941^{* *} ; p=0.012\right.$ ) among the back-ground of respondents. Whereas insignificant influence by other background variables in the regression model were found such as for gender, education, respondent's income, work tenure and age. Whether the employees are men or women, obtained higher education level with higher income, new at work or longer working experience and young or old, these do not affect their presenteeism levels. Earning enough as needed by the family may avoid from stressful situation which may lead to lower presenteeism. Nevertheless, earning less for the family especially in cases where cash-flows are not able to meet financial needs may result in higher presenteeism.

In Model 2 through Model 5, locus of control, materialism, financial stress, work-life balance and health factors were found to be highly significant in influencing presenteeism. Household income in Model 2 onwards became insignificant in its influence on presenteeism when other variables were added in the models. Household income of the employee seems to be not an important factor when other factors such as personal, job and other financial factors exist. The outcome of managing finances that is financial stress is more prevalent than the monetary resources itself.

Locus of control with a negative influence on presenteeism (Model 2: $b=-.330 * * ; p=0.000$ ) portrayed that internally locus of control employees would more likely display less presenteeism hence lower productivity. It retained its significance throughout Model 2 to the final model $(b=-$ $.243^{* *} ; p=0.000$ ). Similarly, Chen and Silverthorne (2008) in their finding on workers' having internal locus of control which could easily cope with job stress indicated that this aspect of personality played an important role in predicting job performance in Taiwan. In the same line, Leone and Burns (2000) contended that internals' believe that the outcomes depend on their words and actions hence will put more efforts in their job.

Materialism was also found to be significantly contributing to presenteeism of the employee with a positive effect as shown in Model 2 to Model 5 (Model 2: $b=.216^{* *} ; p=0.000$; Model 5: $b=.157^{* *}$; $p=0.000$ ). A more materialistic employee would most probably display presenteeism where their focus is diverted from work. Materialism may encouraged people to work more leading to the tendency of generating higher incomes for a greater consumption and higher living standards (Kasser et al., 2007) but researchers are becoming concern that materialism can give more negative consequences to individuals such as depression (Tsang et al., 2014). Highly materialistic values are associated with a lower quality of work life (Deckop et al., 2010) and showing negative organizational citizenship behaviour (Deckop et al., 2015).

In contrast, work-life balance was found to be negatively influencing presenteeism (Model 3: $b=$ $.283^{* *} ; p=0.000$ ) and retaining its significance in Model 4 and 5 . These results are what as expected due to those employees who experience some kind of balance between their work and their life 
INTERNATIONAL JOURNAL OF ACADEMIC RESEARCH IN BUSINESS AND SOCIAL SCIENCES

Vol. 10, No. 16, Youth and Community Wellbeing: Issues, Challenges and Opportunities for Empowerment V2. 2020, E-ISSN: 2222-6990 @ 2020 HRMARS

would be feeling emotionally stable. This would eventually make them focus more on their job as their worries about their life had been casted aside resulting in lower presenteeism. This result was supported by empirical studies that have showed positive effect of work-life balance on employees' performance and organizational performance (Hussein et al., 2018; Johari et al., 2018; Mendis \& Weerakkody, 2014) and on job satisfaction, commitment and productivity (Mukururi \& Ngari, 2014). Nevertheless, poor work-life balance will negatively affect the employees' perceived job stress, hence reducing the productivity of the employees (Bell et al., 2012).

Table 5: Multiple regression analysis for presenteeism model

\begin{tabular}{|c|c|c|c|c|c|c|}
\hline \multirow{2}{*}{\multicolumn{2}{|c|}{ Model }} & \multicolumn{2}{|c|}{ Unstd. Coeff. } & \multirow{3}{*}{$\begin{array}{c}\text { Std. Coeff. } \\
\text { Beta }\end{array}$} & \multirow{3}{*}{$\frac{t}{14.709}$} & \multirow{3}{*}{$\frac{\text { Sig. }}{.000}$} \\
\hline & & \multirow{2}{*}{$\frac{B}{19.683}$} & \multirow{2}{*}{$\begin{array}{c}\text { Std. Error } \\
1.338\end{array}$} & & & \\
\hline 1 & (Constant) & & & & & \\
\hline & Gender (male) & .121 & .539 & .012 & .225 & .822 \\
\hline & Education (graduate) & -.641 & .551 & -.064 & -1.162 & .246 \\
\hline & Respondent income & -.510 & .620 & -.049 & -.822 & .412 \\
\hline & Household income & -1.941 & .771 & -.140 & $-2.516^{*}$ & .012 \\
\hline & Work tenure & .608 & .444 & .160 & 1.367 & .172 \\
\hline & Age & -.098 & .063 & -.179 & -1.563 & .119 \\
\hline 2 & (Constant) & 16.419 & 2.184 & & 7.519 & .000 \\
\hline & Gender (male) & .043 & .476 & .004 & .091 & .928 \\
\hline & Education (graduate) & -.895 & .488 & -.090 & -1.835 & .067 \\
\hline & Respondent income & -.024 & .550 & -.002 & -.043 & .966 \\
\hline & Household income & -.682 & .691 & -.049 & -.987 & .325 \\
\hline & Work tenure & .531 & .392 & .140 & 1.353 & .177 \\
\hline & Age & -.062 & .056 & -.113 & -1.105 & .270 \\
\hline & Locus of control & -.330 & .042 & -.371 & $-7.869 * *$ & .000 \\
\hline & Materialism & .216 & .033 & .303 & $6.567 * *$ & .000 \\
\hline 3 & (Constant) & 24.952 & 2.329 & & 10.715 & .000 \\
\hline & Gender (male) & -.090 & .443 & -.009 & -.204 & .839 \\
\hline & Education (graduate) & -.874 & .454 & -.088 & -1.925 & .055 \\
\hline & Respondent income & -.064 & .512 & -.006 & -.125 & .901 \\
\hline & Household income & .063 & .651 & .005 & .097 & .923 \\
\hline & Work tenure & .465 & .365 & .122 & 1.272 & .204 \\
\hline & Age & -.048 & .052 & -.088 & -.924 & .356 \\
\hline & Locus of control & -.270 & .040 & -.304 & $-6.790 * *$ & .000 \\
\hline & Materialism & .174 & .031 & .244 & $5.584^{* *}$ & .000 \\
\hline & Work-life balance & -.283 & .038 & -.339 & $-7.511^{* *}$ & .000 \\
\hline 4 & (Constant) & 22.568 & 2.432 & & 9.279 & .000 \\
\hline & Gender (male) & -.182 & .439 & -.018 & -.414 & .679 \\
\hline & Education (graduate) & -.784 & .450 & -.079 & -1.743 & .082 \\
\hline
\end{tabular}


INTERNATIONAL JOURNAL OF ACADEMIC RESEARCH IN BUSINESS AND SOCIAL SCIENCES

Vol. 10, No. 16, Youth and Community Wellbeing: Issues, Challenges and Opportunities for Empowerment V2. 2020, E-ISSN: 2222-6990 @ 2020 HRMARS

\begin{tabular}{|l|c|c|c|c|c|}
\hline Respondent income & .112 & .510 & .011 & .219 & .827 \\
\hline Household income & .305 & .649 & .022 & .470 & .639 \\
\hline Work tenure & .406 & .362 & .107 & 1.122 & .263 \\
\hline Age & -.047 & .051 & -.085 & -.907 & .365 \\
\hline Locus of control & -.262 & .039 & -.295 & $-6.639^{* *}$ & .000 \\
\hline Materialism & .158 & .031 & .221 & $5.029^{* *}$ & .000 \\
\hline Work-life balance & -.250 & .039 & -.299 & $-6.443^{* *}$ & .000 \\
\hline Financial stress & .138 & .045 & .144 & $3.042^{* *}$ & .003 \\
\hline (Constant) & 19.531 & 2.592 & & $7.535^{* *}$ & .000 \\
\hline Gender (male) & -.173 & .434 & -.017 & -.399 & .690 \\
\hline Education (graduate) & -.752 & .445 & -.076 & -1.693 & .091 \\
\hline Respondent income & .062 & .504 & .006 & .124 & .902 \\
\hline Household income & .387 & .642 & .028 & .603 & .547 \\
\hline Work tenure & .390 & .357 & .103 & 1.093 & .275 \\
\hline Age & -.045 & .051 & -.082 & -.889 & .374 \\
\hline Locus of control & -.243 & .039 & -.274 & $-6.168^{* *}$ & .000 \\
\hline Materialism & .157 & .031 & .220 & $5.074^{* *}$ & .000 \\
\hline Work-life balance & -.228 & .039 & -.273 & $-5.861^{* *}$ & .000 \\
\hline Financial stress & .121 & .045 & .126 & $2.672^{* *}$ & .008 \\
\hline Health (unhealthy) & .786 & .251 & .138 & $3.125^{* *}$ & .002 \\
\hline
\end{tabular}

a. Dependent Variable: Presenteeism

b. ${ }^{* *} p \leq 0.01 ;{ }^{*} p \leq 0.05$

However when financial stress was included in Model $4\left(b=0.138^{* *} ; p=0.003\right)$ and health in Model $5\left(b=0.121^{* *} ; p=0.008\right)$, both displayed positive significant influences on presenteeism suggesting financial stress an health as another important factors affecting presenteeism. Financially stress employees would most probably using up working time to solve their financial issues and their concentrations are drifted away from their work. As stated by Joo (1998), employees with financial stress may experience a low motivation in their work and diverting the attention on their work. Health was revealed to be positively influencing presenteeism in Model $5\left(b=0.786^{* *} ; p=0.002\right)$ where unhealthy employees will most probably be experiencing higher presenteeism. In line with this, both individual factors and health have been found to lead to presenteeism (Aronsson \& Gustafsson, 2005). Employees who are not fit for work due to deteriorating health conditions would not be able to perform the job efficiently though they are present at work. In terms of completing tasks, those may be achieved at a reduced rate.

Beta coefficients were referred to in determining the relative strength of the contributors where it was found that employees' locus of control $(\beta=-0.274)$ and work-life balance $(\beta=-0.273)$ contribute the most to presenteeism as compared to materialism $(\beta=0.220)$, health $(\beta=0.138)$ or financial stress $(\beta=0.126)$. Being internally locus of control and by having a balance between work and nonwork activities, these enable the employees to have a more stable emotion as he or she can ensure 
that any required activities outside work has been taken care of and then the employee can focus on the job, hence reducing absenteeism.

These results are consistent with past studies where internally locus of control employee will reduce presenteeism at work as they put more effort on their job (Chen \& Silverthorne, 2008; Leone \& Burns, 2000). Personal factors such as personality traits together with health have been found to lead to presenteeism (Aronsson \& Gustafsson, 2005). The importance of work-life balance was proved by empirical studies which found work-life balance to be positively related to employees' performance, organizational performance and job productivity (Ailabouni et al., 2010; Bell et al., 2012; Johari et al., 2018; Mendis \& Weerakkody, 2014; Mukururi \& Ngari, 2014; Muzamil \& Khurshid, 2014) that are negatively influencing presenteeism.

Materialism as the third important factor contributing to presenteeism among these service sector employees was found to be positively influencing presenteeism. As stated by Garoarsdottir and Dittmar (2012), materialistic individuals use fewer money management strategies and high materialism was negatively associated with financial satisfaction (Tang et al., 2011). This may leads materialistic employee more likely to display financial dissatisfaction that will affect work performance. Majority of the employees in this study working in the public service sector were less materialistic then having materialism positively influencing presenteeism of employees, majority of the respondents will display lower presenteeism. Nevertheless, other employees having high materialism will have a tendency to have higher presenteeism. Hence, there is a need to curb high materialistic among employees. This finding is also in line with a study by Deckop et al. (2010) who concluded that those displaying highly materialistic values are associated with a lower quality of work life.

The health condition among these public sector employees was also revealed as another important factor to consider in management decision. Though in terms of strength of contribution on presenteeism was about half of the locus of control, work-life or materialism's strength, health did play a role in presenteeism. Past studies revealed that apart from leading to presenteeism (Aronsson \& Gustafsson, 2005), health is also considered a mediator between stress-related factors at work and presenteeism (Karlsson et al., 2010; Vahtera et al., 2000). Healthy employees would lead to lower presenteeism. In this study, unhealthy employees would result in higher presenteeism or lowered job productivity. Unhealthy employees are still present at work for whatever reasons, however with a deteriorating health condition leading to less productive performance.

A positive effect of financial stress on presenteeism shows that the increase in financial stress of the employee will increase the presenteeism and vice versa. This can be explained by the problems the financially stress employees faced regarding financial matters. They tend to use working time to solve their financial problems or to be thinking it over during work. Thus financially stress employee may lack focus on their work leading to reduced productivity or increased presenteeism. Even for general stress, increased stress was found leading to reduced productivity and the opposite leads to increased productivity (Halkos \& Bousinakis, 2010). International Foundation of Employee Benefit Plans (2016) reported that responses from organizations in the U.S.A. and Canada revealed that workers were struggling and stressed over their financial matters such as on debt (66\%), saving for retirement $(60 \%)$, saving or paying for children's education (51\%), covering basic living expenses (48\%) and 
INTERNATIONAL JOURNAL OF ACADEMIC RESEARCH IN BUSINESS AND SOCIAL SCIENCES

Vol. 10, No. 16, Youth and Community Wellbeing: Issues, Challenges and Opportunities for Empowerment V2. 2020, E-ISSN: 2222-6990 @) 2020 HRMARS

paying for medical expenses (36\%). The stress over these financial issues may spill-out on their work which may be the cause for the low job productivity or high presenteeism.

\section{Conclusion and Implication}

The results revealed locus of control and work-life balance of the employees as the leading contributors followed by other factors that were health, materialism and financial stress for presenteeism of these service sector employees. Hence the integration of personal factors or resources, financial factors and job-related factors contributed to the issue of presenteeism among employees specifically among public sector workers in this study. Personality trait such as internal locus of control, balancing between work and life, being healthy, less materialistic and less financially stress employee predicted low presenteeism whereby avoiding being present at work-place with less focusing on the job among employees. Materialistic individuals who focused more on the possession of things will most probably be stressful if ownership of things were low. Less financially stress employees will be more engaged with their work leading to higher presenteeism, efficient service and leading to higher satisfaction among the customers. Making them aware of the negative consequences on their job productivity may probably make them control their financial stress.

As JD-R model constitutes the need of resources (Demerouti et al., 2001), it suggests that presenteeism may arise from the strain due to lack of resources such as personal resources in the workplace. Personal resources are functional in accomplishing work goals, stimulating personal growth and development of the employees. Presenteeism was becoming a great challenge for a productive workforce. This may lead into more increased awareness of presenteeism and higher demand for health promotion programs in organizations (Cancelliere et al., 2011). As contended by Karthik (2013), successful work life balance enabled employees to control their lives, reducing their work stress and raise job satisfaction and suggested that health care costs should be borne by the organizations. Hence, having necessary steps for maintenance of healthy balance between work and special life gives the opportunity for long term benefits for both employer and employee. These influential factors on presenteeism will assist employers to develop suitable intervention programs to increase positive influential factors and to reduce negative influential factors such as increasing internally locus of control, have a balanced work-life and being healthy, and reducing materialism and financial stress.

Past studies have found that presenteeism causing decreases in productivity can be offset by relatively low costs in screening, treatment and education (Hemp, 2004). Intervention programs for health risk factors are feasible and effective, and having a higher cost-benefit ratio compared to treatment (Wang et al., 2012). Eliminating one risk factor may be able to improve work efficiency by nine per cent and reduce absences by two per cent (Boles et al., 2004). Another study showed savings of $\$ 7$ to $\$ 10$ for every $\$ 1$ spent on health promotion programmes aiming at reducing health risk factors (Goetzel et al., 1999).

Intervention programmes could therefore focus on educating employees how to better manage personal resources as well as promoting the resources available at work as an innovative way to curb the issue of rising presenteeism. The results will enable employers to develop appropriate 
intervention programs in enhancing the quality of personal and financial factors of the employees. Better services are expected to be offered by civil service agencies to the public later and are beneficial for both parties hence customers and employees. Efficient time use would be the consequence of this action thus enabling the growth in economy.

The outcome of lower presenteeism or higher job productivity will be better services rendered by the civil service agencies to the public. Individuals or companies as the clients will be able to experience elevated services and reduced time in their interactions with the agencies. Efficient time use may increase the country's productivity thus enabling the growth in economy. Though this study focuses on public service sector, business organizations may also benefit from the results of this study. Supportive cultures should be the environment in organizations in enhancing the employees' good personal qualities.

\section{Acknowledgement}

This study was funded through Fundamental Research Grant Scheme offered by Ministry of Higher Education Malaysia, KPT FRGS/1/2015/SS03/UPM/02/7.

\section{References}

Abdullah, N., Fazli, S. M., \& Arif, A. M. M. (2019). The relationship between attitude towards money, financial literacy and debt management with young worker's financial well-being. Pertanika Journal of Social Sciences and Humanities, 27(1), 361-387.

Abendroth, A., \& Dulk, L. D. (2011). Support for the work-life balance in Europe: The impact of state, workplace and family support on work-life balance satisfaction. Work, Employment and Society, 25(2), 234-256.

Ailabouni, N., Gidado, K., \& Painting, N. (2010). Factors affecting employee productivity in the UAE construction industry. In Dainty, A. (Ed.), 25th Annual ARCOM Conference, Assoc. of Researchers in Construction Management, 1, 555-564.

Ali, F. R., Mumtaz, M., Tunio, R. A., Mahar, P. R., \& Aslam, A. (2017). Assessing job productivity of employees in higher education institutions: A case study of Jamshoro education city, Sindh, Pakistan. International Journal of Economics, Commerce and Management, 5(1), 351-375.

Angelov, N., Johansson, P., \& Lindahl, E. (2013). Gender differences in sickness absence and the gender division of family responsibilities. Working Paper, IFAU - Institute for Evaluation of Labour Market and Education Policy, No. 2013:9, Institute for Evaluation of Labour Market and Education Policy, Uppsala.

Aronsson, G., \& Gustafsson, K. (2005). Attendance presenteeism: Prevalence, attendance-pressure factors, and an outline of a model for research. Journal of Occupational Environmental Medicine, 47(9), 958-966.

Aronsson, G., Gustafsson, K., \& Dallner, M. (2000). Sick but yet at work. An empirical study of sickness presenteeism. Journal of Epidemiol Community Health, 54(7), 502-509.

Berko, E., Nkuah, J. K., \& Nangpiire, C. (2014). Branding the White Horse Negatively: The Public Procurement Act of Ghana Stands Accused. International Journal of Academic Research in Public Policy and Governace, 1(1), 117-142. 
Bailey, W. C., Woodiel, D. K., Turner, M. J., \& Young, J. B. S. (1998). The relationship of financial stress to overall stress and satisfaction. Personal Finances and Worker Productivity, 2(2), 198-206.

Baker, M., D., Greasley, K., Dale, J., \& Griffith, F. (2010). Absence management and presenteeism: The pressures on employees to attend work and the impact of attendance on performance. Human Resource Management Journal, 20(3), 311-328.

Barclay, K. J. (2013). Sex composition of the workplace and mortality risk. Journal of Biosocial Science, 45, 807-821.

Beaton, D., Bombardier, C., Escorpizo, R., Zhang, W., Lacaille, D., Boonen, A., Osborne, R. H., Anis, A. H., Strand, C. V., \& Tugwell, P. S. (2009). Measuring worker productivity: Frameworks and measures. Journal Rheumatol, 36(9), 2100-2109.

Bell, A. S., Rajendran, D., \& Theiler, S. (2012). Job stress, wellbeing, work-life balance and work-life conflict among Australian academics. Electronic Journal of Applied Psychology, 8(1), 25-37.

Bockerman, P., \& Laukkanen, E. (2010). What makes you work while you are sick? Evidence from a survey of workers. European Journal of Public Health, 20(1), 43-46.

Boles, M., Pelletier, B., \& Lynch, W. (2004). The relationship between health risks and work productivity. Journal of Occupational and Environmental Medicine, 46, 737-745.

Brborovic, H., Brborovic, O., \& Mustajbegovic, J. (2016). Looking for the possible association between stress, presenteeism and absenteeism among Croatian nurses: A cross-sectional study. Iran Journal of Psychiatry Behavioral Science, 10(4), e4587. https://doi.org/10.17795/ijpbs-4587.

Bubonya, M., Cobb-Clark, D. A., \& Wooden, M. (2017). Mental health and productivity at work: does what you do matter? Labour Economics, 46, 150-165.

Cancelliere, C., Cassidy, J. D., Ammendolia, C., \& Cote, P. (2011). Are workplace health promotion programs effective at improving presenteeism in workers? A systematic review and best evidence synthesis of the literature, BMC Public Health, 11(395), 1-11.

Carlson, D. S., Grzywacz, J. G., \& Zivnuska, S. (2009). Is work-family balance more than conflict and enrichment? Human Relation, 62(10), 1-20.

Carrim, N., Basson, J., \& Coetzee, M. (2006). The relationship between job satisfaction and locus of control in a South African call centre environment. South African Journal of Labour Relations, 30(2), 66-81.

Celik, D. A., \& Oz, E. U. (2011). The effects of emotional dissonance and quality of work life perceptions on absenteeism and turnover intentions among Turkish call center employees. Procedia Journal of Social and Behavioral Sciences, 30, 2515-2519.

Chen, J., \& Silverthorne, C. (2008). The impact of locus of control on job stress, job performance and job satisfaction in Taiwan. Leadership \& Organization Development Journal, 29(7), 572-582.

Collins, A., \& Cartwright, S. (2012). Why come into work ill? Individual and organizational factors underlying presenteeism. Employee Relations, 34(4), 429-442.

Daipuria, P., \& Kakar, D. (2013). Work-life balance for working parents: Perspectives and strategies. Journal of Strategic Human Resource Management, 2(1), 45-52.

Deckop, J. R., Jurkiewicz, C. L., \& Giacalone, R. A. (2010). Effects of materialism on work-related personal well-being. Human Relations, 63(7), 1007-1030.

Deckop, J. R., Giacalone, R. A., \& Jurkiewicz, C. L. (2015). Materialism and workplace behaviors: Does wanting more result in less? Social Indicators Research, 121, 787-803. 
Delafrooz, N., Paim, L., Sabri, M. F., \& Masud, J. (2010). Effects of financial wellness on the relationship between financial problem and workplace productivity. World Applied Sciences Journal, 10(8), 871-878.

Delafrooz, N., \& Paim, L. (2011). Determinants of financial wellness among Malaysia workers. African Journal of Business Management, 5(24), 10092-10100.

Delafrooz, N., \& Laily, P. (2013). Role of financial stress on relationship between financial problem and financial wellness among Malaysia workers. African Journal of Business Management, 7(20), 1966-1972.

Demerouti, E., Bakker, A. B., Nachreiner, F., \& Schaufeli, W. B. (2001). The job demands-resources model of burnout. Journal of Applied Psychology, 86(3), 499-512.

Department of Statistic Malaysia. (2020). Report of household income and basic amenities survey 2019. Malaysian Department of Statistic.

Department of Statistic Malaysia. (2016). Household expenditure survey report 2019. Malaysian Department of Statistic.

Dewa, C. S., Lesage, A., Goering, P., \& Craveen, M. (2004). Nature and prevalence of mental illness in the workplace. Healthcare Papers, 5, 12-25.

DiBonaventura, M. D., Wagner, J. S., Yuan, Y., L'Italien, G., Langley, P., \& Kim, W. R. (2011). The impact of hepatitis $\mathrm{C}$ on labor force participation, absenteeism, presenteeism and non-work activities. Journal of Medical Economics, 14, 253-261.

Dittmar, H. (2005). A new look at "Compulsive Buying": Self-discrepancies and materialistic values as predictors of compulsive buying tendency. Journal of Social and Clinical Psychology, 24(6), 832-859.

Dormann, C., Fay, D., Zapf, D., \& Frese, M. (2006). A state-trait analysis of job satisfaction: On the effect of core self-evaluation. Applied Psychology: An International Review, 55(1), 27-51.

Edington, D. W., \& Burton, W. N. (2003). Health and productivity. In McCunney, R. J. (Ed), A practical approach to occupational and environmental medicine (pp. 140). Little, Brown and Co.

Emslie, C., Hunt, K., \& Macintyre, S. (1999). Problematizing gender, work and health: The relationship between gender, occupational grade, working conditions and minor morbidity in full-time bank employees. Social Science Medical, 48(1), 33-48.

Fox, N., Hunn, A., \& Mathers, N. (2007). Sampling and sample size calculation. The NIHR RDS for the East Midlands / Yorkshire \& the Humber.

French, D., \& McKillop, D. (2017). The impact of debt and financial stress on health in Northern Irish households. Journal of European Social Policy, 27(5), 458-473.

Garman, E. T., Leech, I. E., \& Grable, J. E. (1996). The negative impact of employee poor personal financial behaviors on employers. Financial Counseling and Planning, 7, 157-168.

Ghalawat, S., \& Sukhija, S. (2012). Work-life balance and organization practices- A study of selected banks in Sirsa. BVIMR Management Edge, 5(2), 35-44.

Goetzel, R. Z., Juday, T. R., \& Ozminkowski, R. J. (1999). What's the ROI? AWHP'S Worksite Health, 6, 12-21.

Gosselin, E., Lemyre, L., \& Corneil, W. (2013). Presenteeism and absenteeism: Differentiated understanding of related phenomena. Journal of Occupational Health Psychology, 18(1), 7586. 
Greig, F., Hausmann, R., Tyson, L. D., \& Zahidi, S. (2006). The Gender Gap Index 2006: A new framework for measuring equality. In The global gender gap report 2006. World Economic Forum, 2006.

Halkos, G., \& Bousinakis, D. (2010). The effect of stress and satisfaction on productivity. International Journal of Productivity and Performance Management, 59(5), 415-431.

Harrington, B., \& Ladge, J. (2009). Present dynamics and future directions for organizations. Organizational Dynamics, 38(2), 148-157.

Hemp, P. (2004). Presenteeism: At work - but out of it. Harvard Business Review, 82, 49-58.

Hussein, I. H. A., Iliyasu, S. N., Bello, T. A., \& Roshidah, A. (2018). The relationship between job satisfaction, work-life balance and organizational commitment on employee performance. Journal of Business and Management, 20(5), 76-81.

Hobfoll, S. E. (2001). The influence of culture, community, and the nested-self in the stress process: Advancing conservation of resources theory. Applied Psychology, 50, 337-370.

Hoffman, D. L., Novak, T. P., \& Schlosser, A. E. (2003). Locus of control, web sue, and consumer attitudes toward internet regulation. Journal of Public Policy \& Marketing, 22(1), 41-57.

International Foundation of Employee Benefit Plans. (2016). A Report on Financial Education for Today's Workforce: 2016 Survey Results. Brookefield, Wisconsin: International Foundation of Employee Benefit Plans.

Johari, J., Tan, F. Y., \& Zulkarnain, Z. I. T. (2018). Autonomy, workload, work-life balance and job performance among teachers. International Journal of Educational Management, 32(1), 107120.

Johns, G. (2010). Presenteeism in the workplace: A review and research agenda. Journal of Organizational Behaviour, 31, 519-542.

Joo, S. H. (1998). Personal financial wellness and worker job productivity (Virginia Polytechnic Institute and State University), (Doctoral dissertation). Available from Virginia Tech Electronic Theses and Dissertations. (UMI No. 9949872).

Karlsson, M. L., Bjoerklund, C., \& Jensen, I. (2010). The effects of psychosocial work factors on production loss, and the mediating effect of employee health. Journal of Occupational Environmental Medicine, 52, 310-317.

Kamran, A., Zafar, S., \& Ali, S. N. (2014). Impact of work-life balance on employees' productivity and job satisfaction in private sector universities of Pakistan. Proceedings of the Seventh International Conference on Management Science and Engineering Management, 2, 10191029. Doi: 10.1007/978-3-642-40081-0_86

Kasser, T., Cohn, S., Kanner, A. D., \& Ryan, R. M. (2007). Some costs of American corporate capitalism: A psychological exploration of value and goal conflicts. Psychological Inquiry, 18, 1-22.

Kessler, R. C., Barber, C., Beck, A., Berglund, P., Cleary, P. D., Mckenas, D., Pronk N., Simon, G., Stang, P., Ustun, T. B., \& Wang, P. (2003). The World Health Organization health and work performance questionnaire (HPQ). Journal of Occupational and Environmental Medicine, 45(2), 156-174.

Kim, J., \& Garman, E. T. (2003). Financial stress and absenteeism: An empirically derived model. Financial Counseling and Planning, 14(1), 31-42. 
INTERNATIONAL JOURNAL OF ACADEMIC RESEARCH IN BUSINESS AND SOCIAL SCIENCES

Vol. 10, No. 16, Youth and Community Wellbeing: Issues, Challenges and Opportunities for Empowerment V2. 2020, E-ISSN: 2222-6990 @) 2020 HRMARS

Kim, J., Sorhaindo, B., \& Garman, E. (2006). Relationship between financial stress and workplace absenteeism of credit counseling clients. Journal of Family and Economic Issues, 27(3), 458478.

Krishnan, B. C., Netenmeyer, R. G., \& Boles, J. S. (2003). Self-efficacy, competitiveness, and effort as antecedents of salesperson performance. Journal of Personal Selling \& Sales Management, 22(4), 285-295.

Leineweber, C., Westerlund, H., Hagberg, J., Svedberg, P., Luokkala, M., \& Alexanderson, K. (2011). Sickness presenteeism among Swedish police officers. Journal of Occupational Rehabilitation, 21(1), 17-22.

Leone, C., \& Burns, J. (2000). The measurement of locus of control: assessing more than meets the eye? The Journal of Psychology, 134(1), 63-76.

Lim, Y. K. G., \& Teo, S. H. (1998). Effects of individual characteristics on police officers' work-related attitudes. Journal of Managerial Psychology, 13, 334-442.

Malaysian Department of Insolvency. (2020). Bankruptcy statistics. Malaysian Department of Insolvency.

Malaysian Productivity Corporation. (2018). Productivity report 2017/2018. Malaysian Productivity Corporation.

Marzec, M. L. (2013). Determinants of absenteeism according to health risk appraisal data (University of Michigan), (Doctoral dissertation). Available from ProQuest Dissertations \& Theses database. (UMI No. 3595456).

Marzec, M. L., Scibelli, A., \& Edington, D. (2015). Impact of changes in medical condition burden index and stress on absenteeism among employees of a US utility company. International Journal of Workplace Health Management, 8, 15-33.

McGregor, A., Magee, C. A., Caputi, P., \& Iverson, P. (2016). A job demands-resources approach to presenteeism. Career Development International, 21(4), 402-418.

McShane, S. L., \& Glinow, M. A. V. (2010). Organizational behavior. McGraw-Hill/Irvin.

Mendis, M. D. V. S., \& Weerakkody, W. A. S. (2014). The relationship between work life balance and employee performance: With reference to telecommunication industry of Sri Lanka. Kelaniya Journal of Human Resource Management, 9(1), 95-117.

Mokhtar, N., \& Husniyah, A. R. (2017). Determinants of financial well-being among public employees in Putrajaya, Malaysia. Pertanika Journal of Social Science and Humanities, 25(3), 1241-1260.

Mukururi, J. N., \& Ngari, J. M. (2014). Influence of work life balance policies on employee job satisfaction in Kenya's banking sector: A case of commercial banks in Nairobi central business district. Journal of Humanities and Social Science, 19(3), 102-112.

Muzamil, K., \& Khurshid, B. (2014). Analysis of labour productivity of road construction in Pakistan. International Journal of Engineering and Advanced Technology, 3(3), 153-159.

Netemeyer, R. G., Boles, J. S., \& McMurrian, R. (1996). Development and validation of work-family conflict and family-work conflict scales. Journal of Applied Psychology, 81(4), 400-410.

Noe, R. A., Hollenbeck, J. R., Gerhart, B., \& Wright, P. M. (2016). Fundamentals of human resource management ( $6^{\text {th }}$ ed.). McGraw-Hill Education.

Oloke, O. C., Oni, A. S., Babalola, D. O., \& Ojelabi, R. A. (2017). Incentive package, employee's productivity and performance of real estate firms in Nigeria. European Scientific Journal, 13(11), 246-260. 
Patel, M. R., Kruger, D. J., Cupal, S., \& Zimmerman, M. (2016). Effect of financial stress and positive financial behaviors on cost-related nonadherence to health regimens among adults in a community-based setting. Preventing Chronic Disease, 13(E46), 1-11.

Patton, E., \& Johns, G. (2007). Women's absenteeism in the popular press: Evidence for a genderspecific absence culture. Human Relations, 60(11), 1579-1612.

Peirce, R. S., Frone, M. R., \& Russell, M. (1996). Financial stress, social support, and alcohol involvement: A longitudinal test of the buffering hypothesis in a general population survey. Health Psychology, 15(1), 38-47.

Pirog, S. F., \& Roberts, J. A. (2007). Personality and credit card misuse among college students: The mediating role of impulsiveness. Journal of Marketing Theory and Practice, 15(1), 65-77.

Pit, S., \& Hansen, V. (2016). The relationship between lifestyle, occupational health and work-related factors with presenteeism amongst general practitioners. Archive Environmental Occupatiional Health, 71, 49-56.

Ponchio, M. C., \& Aranha, F. (2008). Materialism as a predictor variable of low income consumer behaviour when entering into installment plan agreements. Journal of Consumer Behaviour, 7, 21-34.

Promislo, M. D., Deckop, J. R., Giacalone, R. A., \& Jurkiewicz, C. L. (2010). Valuing money more than people: The effects of materialism on work-family conflict. Journal of Occupational and Organizational Psychology, 84(4), 935-953.

Rego, A., \& Cunha, P. M. (2009). Do the opportunities for learning and personal development lead to happiness? It depends on work-family conciliation. Journal of Occupational Health Psychology, 14(3), 334-348.

Richins, M. L., \& Dawson, S. (1992). A consumer values orientation for materialism and its measurement: Scale development and validation. Journal of Consumer Research, 19(3), 303316.

Richins, M. L. (2004). The material values scale: Measurement properties and development of a short form. Journal of Consumer Research, 31(1), 209-219.

Rosvold, E. O., \& Bjertness, E. (2002). Illness behaviour among Norwegian physicians. Scandinavia Journal of Public Health, 30(2), 125-32.

Sabri, M. F., Wijekoon, R., \& Rahim, H. A. (2020). The influence of money attitude, financial practices, self-efficacy and emotion coping on employees' financial well-being. Management Science Letters, 10(2020), 889-900.

Schultz, A. B., Chen, C. Y., \& Edington, D. W. (2009). The cost and impact of health conditions on presenteeism to employers a review of the literature. Pharmacoeconomics, 27(5), 365-378.

Schultz, A. B., \& Edington, D. W. (2007). Employee health and presenteeism: A systematic review. Journal of Occupational Rehabilitation, 17, 547-579.

Shrum, L. J., Wong, N., Arif, F., Chugani, S. K., Gunz, A., Lowrey, T. M., Nairn, A., Pandelaere, M., Ross, S. M., Ruvio, A., Scott, K., \& Sundie, J. (2013). Reconceptualizing materialism as identity goal pursuits: Functions, processes, and consequences. Journal of Business Research, 66(8), 11791185.

Steultjens, E., Baker, N., \& Aas, R. W. (2012). Organizational leadership, health risk screening, individually tailored programs, and supportive workplace culture might reduce presenteeism. Australian Occupational Therapy Journal, 59, 247-248. 
Sweet, E., Nandi, A., Adam, E. K., \& McDade, T. W. (2013). The high price of debt: Household financial debt and its impact on mental and physical health. Social Science \& Medicine, 91, 94-100.

Tang, T. L., Luna-Arocas, R., Pardo, I. Q., \& Tang, T. L. (2011). Materialism and the dark side of the financial dream in Spain: The positive role of love of money as a suppressor. Applied Psychology: An International Review, 63(3), 480-508.

Terry, P. E., \& Xi, M. (2010). An examination of presenteeism measures: The association of three scoring methods with health, work life, and consumer activation. Population Health Management, 13, 297-307.

Tsang, J., Carpenter, T. P., Roberts, J. A., Frisch, M. B., \& Carlisle, R. D. (2014). Why are materialists less happy? The role of gratitude and need satisfaction in the relationship between materialism and life satisfaction. Personality and Individual Differences, 64, 62-66.

Vahtera, J., Kivimaki, M., Pentti, J., \& Theorell, T. (2000). Effect of change in the psychosocial work environment on sickness absence: A seven year follow up of initially healthy employees. Journal of Epidemiology Community, 54, 484-493.

Van den Heuvel, S. G., Geuskens, G. A., Hooftman, W. E., Koppes, L. L. J., \& Van den Bossche, S. N. (2010). Productivity loss at work; health-related and work-related factors. Journal of Occupational Rehabilitation, 20, 331-339.

Vanni, K., Virtanen, P., Luukkaala, T., \& Nygard, C. H. (2012). Relationship between perceived work ability and productivity loss. International Journal of Occupational Safety Ergonomics, 18, 299309.

Vedhara, K., Gill, S., Eldesouky, L., Campbell, B. K., Arevalo, J. M. G., Ma, J., \& Cole, S. W. (2015). Personality and gene expression: Do individual differences exist in the leukocyte transcriptome? Psychoneuroendocrino, 52, 72-82.

Wang, Y. F., Lim, H., \& Wu, Y. (2012). Growing global burden of chronic noncommunicable diseases and an alarming situation in China. Beijing Da Xue Xue Bao, 44, 688-693.

Wee, L., Yeap, L., Chan, C., Wong, J. E., Jamil, N. A., Nantha, Y. S., \& Siau, C. S. (2019). Anteceding factors predicting absenteeism and presenteeism in urban area in Malaysia. BMC Public Health, 19, 540. https://doi.org/10.1186/s12889-019-6860-8.

Williams, C. (2007). Management (4th edition). Thomson Higher Education.

Williams, F. L., Haldeman, V., \& Cramer, S. (1996). Financial concerns and productivity. In Proceedings of Association for Financial Counseling and Planning Education, 147-155.

Worthington, A. C. (2006). Debt as a source of financial stress in Australian household. International Journal of Consumer Studies, 30(1), 2-15.

Xiaoqian, D., \& Jianshi, H. (2010). A study of the association between employee's health risk factors and health-related productivity loss in a hospital of Jinan, Shandong Province, China. Peking Union Medical College, 5.

Yang, T., Zhu, M., \& Xie, X. (2016). The determinants of presenteeism: A comprehensive investigation of stress-related factors at work, health, and individual factors among the aging workforce. Journal of Occupational Health, 58, 25-35.

Yildiz, H., Yildiz, B., Zehir, C., \& Aykac, M. (2015). The antecedents of presenteeism and sickness absenteeism: A research in Turkish health sector. Procedia Journal of Social and Behavioral Sciences, 207, 398-403. 
INTERNATIONAL JOURNAL OF ACADEMIC RESEARCH IN BUSINESS AND SOCIAL SCIENCES

Vol. 10, No. 16, Youth and Community Wellbeing: Issues, Challenges and Opportunities for Empowerment V2. 2020, E-ISSN: 2222-6990 @ 2020 HRMARS

Yu, J., Wang, S., \& Yu, X. (2015). Health risk factors associated with presenteeism in a Chinese enterprise. Occupational Medicine, 65(9), 732-738. 